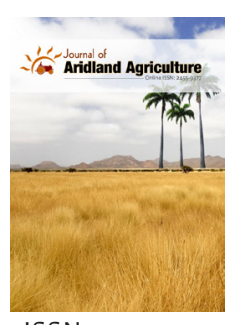

ISSN: $2455-9377$
Received: March 07, 2021

Revised: July 26, 2021

Accepted: July 27, 2021

Published: August 05, 2021

*Corresponding Authors: Sang Un Park;

E-mail: supark@cnu.ac.kr Yong Suk Chung;

E-mail: yschung@jejunu.ac.kr

\section{Effect of cytokinins on growth and phenylpropanoid accumulation in Tartary buckwheat sprouts (Fagopyrum esculentum Moench)}

\author{
Ramaraj Sathasivam', Min Cheol Kim', Yong Suk Chung ${ }^{2 *}$ and \\ Sang Un Park ${ }^{1,3 *}$ \\ 'Department of Crop Science, Chungnam National University, 99 Daehak-ro, Yuseong-gu, Daejeon 34134, Korea, \\ ${ }^{2}$ Department of Plant Resources and Environment, College of Applied Life Sciences, Jeju National University, \\ 102 Jejudaehak-ro, Jeju-si, Jeju 63243, Korea, ${ }^{3}$ Department of Smart Agriculture Systems, Chungnam National \\ University, 99 Daehak-ro, Yuseong-gu, Daejeon 34134, Korea
}

\begin{abstract}
This study analyzed the effect of plant hormones, zeatin, 6-benzyl amino purine (BAP), kinetin, and thidiazuron (TDZ) on the growth of Tartary buckwheat sprouts and analyzed the fresh weight, shoot and root length, and production of phenolic compounds. All the hormone-treated plants at the lowest concentration $(0.1 \mathrm{mg} / \mathrm{L})$ showed the highest levels of growth parameters (fresh weight, shoot, and root length) when compared to the control. Among the various hormones treatment, the plant treated with $1 \mathrm{mg} / \mathrm{L}$ of BAP, kinetin, and zeatin showed the highest total phenolic level, whereas the TDZ showed the highest accumulation of total phenolic at the lowest concentration $(0.1 \mathrm{mg} / \mathrm{L})$. A total of 6 compounds were identified (4-hydroxybenzoic acid, caffeic acid, chlorogenic acid, $p$-coumaric acid, rutin, and trans-cinnamic acid) were quantified by high liquid performance chromatography (HPLC) after treatment of plant with different concentrations of hormones. Among these individual phenolic compounds, at the higher hormonal concentration $(1 \mathrm{mg} / \mathrm{L})$ the rutin showed the highest accumulation in BAP, zeatin, and kinetin treated sprout, whereas in the TDZ treated sprout the rutin content was highest at the lowest concentration $(0.1 \mathrm{mg} / \mathrm{L})$. From these results, it is suggested that BAP, zeatin, and kinetin at the lowest concentrations might positively enhance the growth of buckwheat sprouts, whereas at the highest hormonal treatment the accumulation of the phenolic compounds was higher. However, in TDZ treatment the growth and phenolic compound accumulation were highest at the lowest concentration. From these results, it is showed that suitable concentrations might enhance the growth and phenolic compound accumulation in Tatary buckwheat sprout.
\end{abstract}

KEY WORDS: Tartary buckwheat, Fagopyrum esculentum Moench, phenylpropanoid, zeatin, 6-benzyl amino purine, kinetin, thidiazuron

\section{INTRODUCTION}

Fagopyrum esculentum Moench is called common buckwheat, and it is mainly grown and consumed in the countries such as China, South Korea, and Japan (Jeon et al., 2007). The buckwheat is considered as one of the most important pseudocereals due to its agricultural and various medicinal properties such as anti-allergic (Kim et al., 2003), antibacterial (Amarowicz et al., 2008), biological activities, anti-hypertensive (Kim et al., 2009), antioxidant (Ren \& Sun, 2014), and cytotoxic (Danihelová et al., 2013), and allelopathic effect (Golisz et al., 2007). These properties prove that the common buckwheat consists of various nutrients such as amino acids, dietary fibers, dietary flavonoids, minerals, fatty acids, phenolic compounds, and vitamins (Golisz et al., 2007; Kim et al., 2009).

The phenylpropanoid pathway is one of the largest groups of benzo- $\gamma$-pyrone derivatives and ubiquitously distributed in plant species (Kumar \& Pandey, 2013). This pathway byproduct is mainly involved in the growth and development of the plant, disease protection, pigment generation, and photoprotection (Dixon \& Paiva, 1995; Winkel, 2001). Previously several studies reported that the common buckwheat contains phenolic compounds such as (-)-epicatechin), (+)-catechin, caffeic acid, chlorogenic acid,

Copyright: $\odot$ The authors. This article is open access and licensed under the terms of the Creative Commons Attribution License (http://creativecommons.org/licenses/by/4.0/) which permits unrestricted, use, distribution and reproduction in any medium, or format for any purpose, even commercially provided the work is properly cited. Attribution - You must give appropriate credit, provide a link to the license, and indicate if changes were made. 
ferulic acid, quercetin, gallic acid, and rutin (Golisz et al., 2007). Among these individual carotenoids, rutin is the main component present in common buckwheat (Kalinova et al., 2006; Kreft et al., 2006; Golisz et al., 2007; Jiang et al., 2007; Kim et al., 2008). Rutin obtained from buckwheat species such as F. homotropicum, F. tataricum, and F. esculentum showed several health benefits such as antidiabetic (Watanabe \& Ayugase, 2010), anti-neuroprotective (Gulpinar et al., 2012), anti-inflammatory (Lee et al., 2013), antioxidant (Jiang et al., 2007), cytotoxic effects (Kim et al., 2007), and cardiac hypertrophy inhibition (Han et al., 2010).

Plant hormones are otherwise called phytohormones, are well-defined as organic molecules and even at a low concentration, it has a positive effect on plant physiological processes such as growth and development, and differentiation (Davies, 2010). In-plant tissue culture and cell culture, the phytohormones are divided into 5 main classes namely, abscisic acid (ABA), auxins, ethylene, cytokinins, and gibberellins (GAs). Mostly, the interaction of auxin and cytokinin is essential for the regulation of physiological developments in plant tissue and organ cultures. However, the ABA, GAs, and ethylene play regulatory roles in the cultures (Gaspar et al., 1996).

In further, the production of medicinally valuable secondary metabolites has been made through various strategies such as culture systems, elicitation, nutrient conditions, plant hormones, precursor feeding, and removal of toxic products (Cho et al., 1988; Yeoman \& Yeoman, 1996; Rao \& Ravishankar, 2002; Vanisree et al., 2004; Karuppusamy, 2009). Specifically, treatment of plants with hormones will enhance the secondary metabolites production, for example, treatment of buckwheat plantlets with 6-benzyl adenine increases the concentrations of rutin (Hou et al., 2015); in Brassica rapa spp. pekinensis the ABA increases the phenolic and glucosinolates content (Thiruvengadam et al., 2015) and in Vitis rotundifolia the ABA treatment enhances the production of anthocyanin and flavonol compounds (Sandhu et al., 2011). In cell cultures of Catharanthus roseus, ethylene hormone improved the accumulation of alkaloids (Yahia et al., 1998). In addition, the adventitious roots of Periploca sepium Bunge treated with indolebutyric acid, increase the production of Periplocin (Zhang et al., 2012); Moreover, treatment of Tartary buckwheat "Hokkai T10" cultivar with appropriate concentration of auxins (indole-3-acetic acid, 2,4-dichlorophenoxyacetic acid, indolebutyric acid, naphthaleneacetic acid) will enhance the production of the anthocyanin in hairy root cultures (Park et al., 2016).

To the best of our knowledge, there were no previous reports on the effect of zeatin, benzyl amino purine (BAP), kinetin, and thidiazuron (TDZ) on the accumulation of phenolic compounds in common buckwheat sprouts. Thus, in this study, we aim to optimize the suitable concentration of BAP, kinetin, zeatin, and TDZ to enhance the growth and production of phenolic compounds especially the rutin content in common buckwheat sprouts.

\section{MATERIALS AND METHODS}

\section{Plant Materials}

Tartary buckwheat seeds were purchased from Jeju, and it was soaked into the water for $16 \mathrm{~h}$ at room temperature. The next day, the soaked seeds were sowed into the pot containing vermiculites and germinated at $25^{\circ} \mathrm{C}$ in a plant growth chamber consist of white cool fluorescent lights $\left(35 \mu \mathrm{mol} \mathrm{s}{ }^{-1} \mathrm{~m}^{-2}\right)$ with 16/8-h light/dark period. For hormonal treatment, the plants were treated with different concentrations $(0.1,0.5$, and $1.0 \mathrm{mg} / \mathrm{L}$ ) of BAP, kinetin, zeatin, and TDZ. The grown sprout was harvested after 10 days and measured the fresh weight, shoot, and root length. Then the samples were immediately frozen by using $-196^{\circ} \mathrm{C}$ liquid nitrogen and stored at deep freezer $\left(-80^{\circ} \mathrm{C}\right)$. After freeze-dried the samples were ground into powdered and $100 \mathrm{mg}$ of each powdered sample were taken for HPLC analysis.

\section{Chemical and Standards}

All the plant hormones (Zeatin, BAP, kinetin, and TDZ) and the HPLC external standards such as caffeic acid, chlorogenic acid, p-coumaric acid, trans-cinnamic acid, and rutin were purchased from Sigma-Aldrich Co., Ltd., St. Louis, MO, USA, whereas hydroxybenzoic acid purchased from Extrasynthese, Genay, France.

\section{Extraction and Analysis of Phenylpropanoid Compounds}

The extraction and analysis of phenylpropanoid compounds in the common buckwheat sprouts were carried out with little modification as previously described by Yeo et al. (2021). A total of $0.1 \mathrm{~g}$ of finely powdered Tartary buckwheat sprout were mixed with $3 \mathrm{ml}$ of methanol solution (80\%). Then vortexed well for $1 \mathrm{~min}$ and sonicated it for $1 \mathrm{~h}$ at $37^{\circ} \mathrm{C}$. The mixture was centrifuged at $4{ }^{\circ} \mathrm{C}$ for $15 \mathrm{~min}$ at $10,000 \mathrm{rpm}$. The supernatant was passed through the PTFE syringe filter into a glass vial. The HPLC machine, mobile phase, HPLC condition, gradient program, identification, and quantification of phenolic compounds were similar to that of the protocol of Yeo et al. (2021).

\section{Statistical Analysis}

Data were analysis was done by using the SPSS statistics, version 26 (IBM Corp, Armonk, NY, USA), and Duncan's multiple range test was performed to determine significant differences. All experimental analyses were analyzed in triplicates.

\section{RESULTS AND DISCUSSION}

\section{Effect of BAP, Kinetin, Zeatin, and TDZ on Growth Characteristics}

The growth pattern of buckwheat sprouts at different growth regulators (BAP, kinetin, zeatin, and TDZ) was observed by 


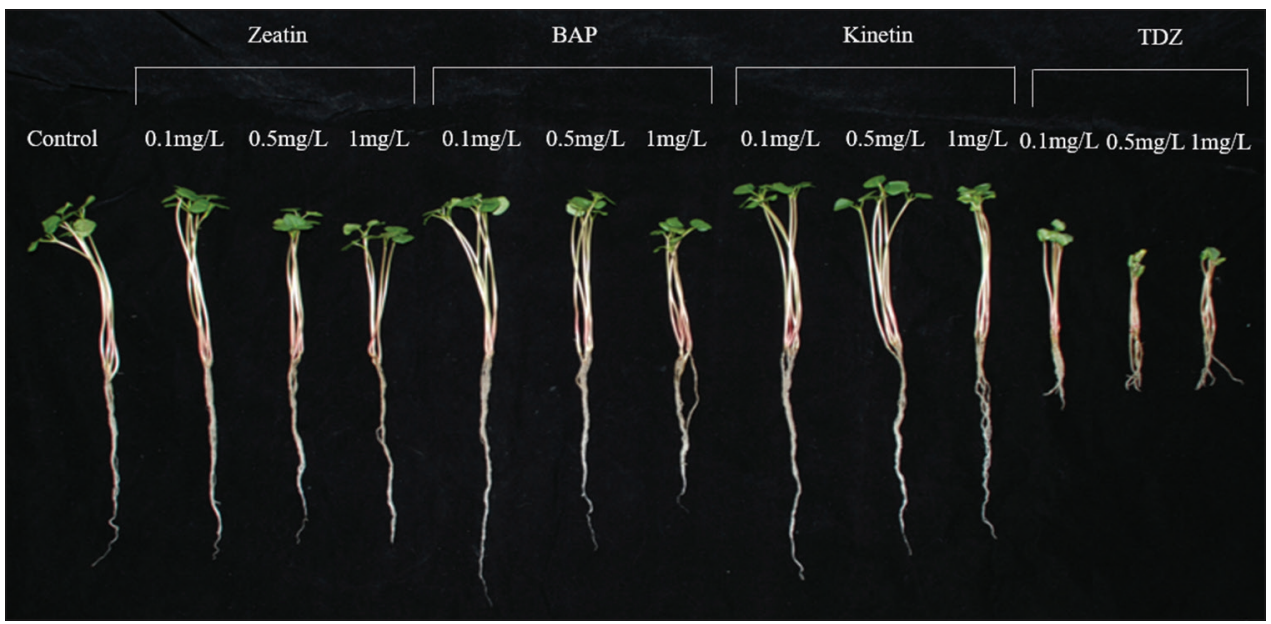

Figure 1: The effect of zeatin, BAP, kinetin, and TDZ on Tartary buckwheat sprout growth

measuring its fresh weight $(\mathrm{g})$, shoot, and root length $(\mathrm{cm})$. The result showed that different growth regulators exhibit similar growth patterns (Figure 1). At the lowest concentration $(0.1 \mathrm{mg} / \mathrm{L})$, in all the exogenous supplied plant hormones (BAP, kinetin, zeatin, and TDZ) the fresh weight, shoot, and root length were highest when compared to the control and other concentrations $(0.5$ and $1.0 \mathrm{mg} / \mathrm{L})$. The control represents that without the addition of exogenous hormones for 10 days. Among the different growth regulators, the highest fresh weight was achieved in $0.1 \mathrm{mg} / \mathrm{L} \mathrm{BAP,} \mathrm{and} \mathrm{it} \mathrm{was} \mathrm{1.24-,} \mathrm{1.06-,} \mathrm{1.05-,}$ and 1.69- times higher than that of the control, $0.1 \mathrm{mg} / \mathrm{L}$ of zeatin, kinetin, and TDZ, respectively (Figure 2). Similar results were obtained in the shoot and root length; both lengths were highest in the $0.1 \mathrm{mg} / \mathrm{L}$ BAP treatment, whereas at the highest concentrations $(0.5$ and $1.0 \mathrm{mg} / \mathrm{L})$ the shoot and root length were lowered in all the hormonal treatments. The shoot and root length of $0.1 \mathrm{mg} / \mathrm{L}$ BAP treated sprout was (11.24 \pm 0.25 and

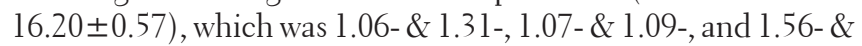
3.29- higher than that of the other $0.1 \mathrm{~g} / \mathrm{L}$ hormonal treatments (zeatin, kinetin, and TDZ), respectively. Among all the growth regulators, the TDZ treatment at different concentrations showed the lowest fresh weight, shoot and root length. From these results, it is showed that BAP at the lowest concentration $(0.1 \mathrm{mg} / \mathrm{L})$ significantly enhances the fresh weight, shoot and root length in the Tartary buckwheat sprout.

From the growth characteristic results, it is showed that the BAP enhances the growth of buckwheat sprouts. Several studies have been reported that BAP enhances the growth of plants. El Kbiach et al. (2002) reported that BAP enhanced the axillary bud sprouting in Quercus suber L. and they found that BAP is one of the best growth regulators. In addition, they have reported that the absence of stem on different control culture medium proves that cytokinins are important for the development of aerial organs in plants when compared to auxins (El Kbiach et al., 2002). In strawberries, the BAP treatment enhances the fresh matter weight (Hunter et al., 1984). This result was an agreement with the previous study, in nature the differences of growth on the various genotype of Dioscorea sp. is determined by the amount of cytokinin (Saleil et al., 1990). In addition, it

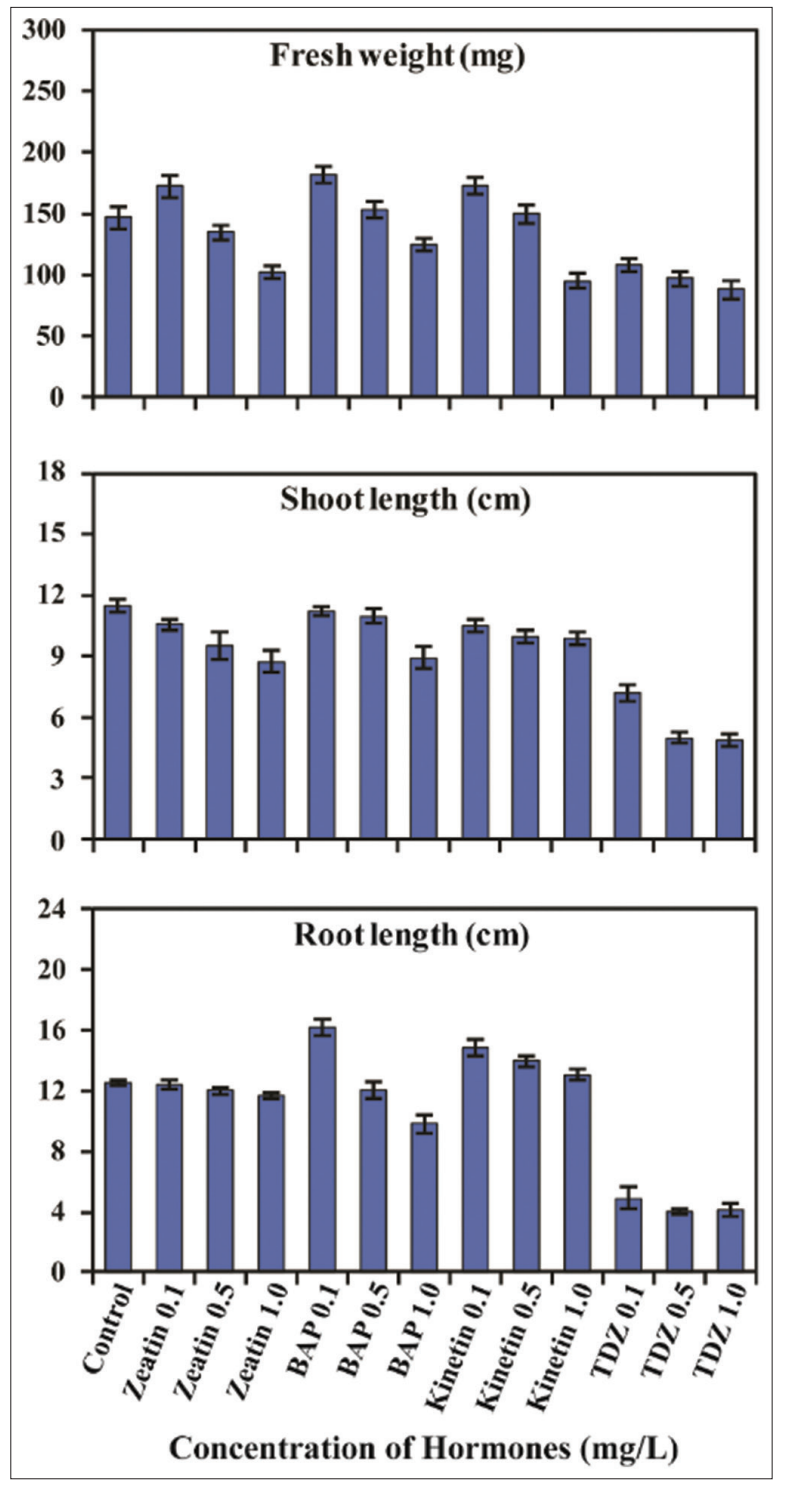

Figure 2: Effect of different hormones in Tartary buckwheat sprout growth characteristics at different concentrations. Data were analysed after 10 days of growth. 
Table 1: Effect of zeatin, BAP, Kinetin, and TDZ on accumulation of phenolic compounds in common buckwheat sprouts.

\begin{tabular}{|c|c|c|c|c|c|c|c|c|}
\hline \multirow[t]{2}{*}{ Plant Hormones } & \multirow{2}{*}{$\begin{array}{c}\text { Concentrations } \\
(\mathrm{mg} / \mathrm{L})\end{array}$} & \multicolumn{7}{|c|}{ Phenolic compounds (mg/g DW) } \\
\hline & & 4-hydroxybenzoic acid & Chlorogenic acid & Caffeic acid & $p$-coumaric acid & Rutin & trans-cinnamic acid & Total \\
\hline Control & 0 & $0.19 \pm 0.01 a$ & $0.01 \pm 0.00 \mathrm{~b}$ & $0.54 \pm 0.02 a$ & $0.03 \pm 0.00 c$ & $23.15 \pm 0.74 b$ & $0.06 \pm 0.01 \mathrm{a}$ & $23.99 \pm 0.75 b$ \\
\hline \multirow[t]{3}{*}{ Zeatin } & 0.1 & $0.14 \pm 0.01 d$ & $0.01 \pm 0.00 \mathrm{~b}$ & $0.39 \pm 0.06 d$ & $0.04 \pm 0.00 b$ & $20.49 \pm 0.46 c$ & $0.05 \pm 0.01 b$ & $21.12 \pm 0.38 c$ \\
\hline & 0.5 & $0.16 \pm 0.00 c$ & $0.02 \pm 0.00 \mathrm{a}$ & $0.46 \pm 0.00 b$ & $0.05 \pm 0.00 a$ & $23.95 \pm 1.36 b$ & $0.06 \pm 0.00 \mathrm{a}$ & $24.68 \pm 1.35 a$ \\
\hline & 1.0 & $0.18 \pm 0.01 b$ & $0.02 \pm 0.00 \mathrm{a}$ & $0.45 \pm 0.02 c$ & $0.04 \pm 0.00 b$ & $24.22 \pm 2.41 a$ & $0.05 \pm 0.00 b$ & $24.95 \pm 2.39 a$ \\
\hline Control & 0 & $0.19 \pm 0.01 b$ & $0.01 \pm 0.00 \mathrm{a}$ & $0.54 \pm 0.02 b$ & $0.03 \pm 0.00 b$ & $23.15 \pm 0.74 c$ & $0.06 \pm 0.01 \mathrm{a}$ & $23.99 \pm 0.75 c$ \\
\hline \multirow[t]{3}{*}{ BAP } & 0.1 & $0.25 \pm 0.00 \mathrm{a}$ & $0.01 \pm 0.00 \mathrm{a}$ & $0.53 \pm 0.01 c$ & $0.03 \pm 0.00 b$ & $22.60 \pm 1.72 d$ & $0.06 \pm 0.00 \mathrm{a}$ & $23.48 \pm 1.72 c$ \\
\hline & 0.5 & $0.18 \pm 0.01 c$ & $0.01 \pm 0.00 \mathrm{a}$ & $0.50 \pm 0.01 d$ & $0.03 \pm 0.00 b$ & $24.79 \pm 0.55 b$ & $0.04 \pm 0.00 \mathrm{~b}$ & $25.55 \pm 0.56 b$ \\
\hline & 1.0 & $0.17 \pm 0.01 d$ & $0.01 \pm 0.00 \mathrm{a}$ & $0.61 \pm 0.02 a$ & $0.04 \pm 0.01 a$ & $26.49 \pm 0.61 a$ & $0.04 \pm 0.00 \mathrm{~b}$ & $27.36 \pm 0.56 a$ \\
\hline Control & 0 & $0.19 \pm 0.01 a$ & $0.01 \pm 0.00 \mathrm{a}$ & $0.54 \pm 0.02 b$ & $0.03 \pm 0.00 a$ & $23.15 \pm 0.74 c$ & $0.06 \pm 0.01 b$ & $23.99 \pm 0.75 c$ \\
\hline \multirow[t]{3}{*}{ Kinetin } & 0.1 & $0.16 \pm 0.01 b$ & $0.01 \pm 0.00 \mathrm{a}$ & $0.46 \pm 0.03 c$ & $0.03 \pm 0.00 \mathrm{a}$ & $24.46 \pm 1.28 b$ & $0.04 \pm 0.00 c$ & $25.17 \pm 1.26 b$ \\
\hline & 0.5 & $0.16 \pm 0.01 b$ & $0.01 \pm 0.00 \mathrm{a}$ & $0.42 \pm 0.02 d$ & $0.03 \pm 0.00 \mathrm{a}$ & $22.99 \pm 2.46 d$ & $0.06 \pm 0.00 b$ & $23.67 \pm 2.49 c$ \\
\hline & 1.0 & $0.16 \pm 0.01 b$ & $0.01 \pm 0.00 \mathrm{a}$ & $0.58 \pm 0.02 \mathrm{a}$ & $0.03 \pm 0.00 \mathrm{a}$ & $28.73 \pm 1.07 a$ & $0.08 \pm 0.00 \mathrm{a}$ & $29.59 \pm 1.04 a$ \\
\hline Control & 0 & $0.19 \pm 0.01 a$ & $0.01 \pm 0.00 \mathrm{a}$ & $0.54 \pm 0.02 \mathrm{a}$ & $0.03 \pm 0.00 b$ & $23.15 \pm 0.74 d$ & $0.06 \pm 0.01 b$ & $23.99 \pm 0.75 d$ \\
\hline \multirow[t]{3}{*}{ TDZ } & 0.1 & $0.13 \pm 0.00 b$ & $0.01 \pm 0.00 \mathrm{a}$ & $046 \pm 0.00 b$ & $0.04 \pm 0.00 \mathrm{a}$ & $29.16 \pm 0.27 a$ & $0.06 \pm 0.00 b$ & $29.86 \pm 0.26 a$ \\
\hline & 0.5 & $0.10 \pm 0.00 c$ & $0.01 \pm 0.00 \mathrm{a}$ & $0.36 \pm 0.00 d$ & $0.03 \pm 0.00 b$ & $26.89 \pm 0.29 b$ & $0.10 \pm 0.00 \mathrm{a}$ & $27.49 \pm 0.29 b$ \\
\hline & 1.0 & $0.09 \pm 0.00 d$ & $0.01 \pm 0.00 \mathrm{a}$ & $0.39 \pm 0.02 c$ & $0.03 \pm 0.00 b$ & $25.58 \pm 0.29 c$ & $0.06 \pm 0.00 \mathrm{~b}$ & $26.16 \pm 0.27 c$ \\
\hline
\end{tabular}

Mean with different letters $(a, b, c$, and $d$ ) in the same column differ significantly $(p<0.05$, ANOVA, DMRT)

has been reported that cytokinins trigger and enhance the dry matter mass of the bublets of Dioscorea bulbifera (Mantell \& Hugo, 1989). Moreover, in the micropropagation of banana plants, the BAP showed high efficiency than the zeatin (De Langhe \& Vuylstek, 1985). A similar result was obtained in the Afassie Blanche, a Togolese variety (Toklo, 2000). In another study, when compared to kinetin, the highest shoot growth for other yam varieties of Benin was obtained in BAP (Montcho, 2004). Ahanhanzo et al. (2010), studied the effect of two growth regulators (BAP and Zeatin) on yams varieties and they found that BAP showed the highest bud sprouting and development of shoot. In addition, they concluded that when compared to zeatin the BAP is considered to be one of the important cytokinins which have the best morphogenic aptitude in yam micropropagation (Ahanhanzo et al., 2010). Based on these, the response of explants and mode of action of cytokinins is mainly dependent on the genotype of the plants. From these overall results it is showed that among the different growth regulators, the BAP is useful for enhancing the growth of plants.

\section{Effect of BAP, Kinetin, Zeatin, and TDZ on Phenolic Compounds}

In the HPLC analysis, a total of 6 phenolic compounds were identified and quantified in the Tartary buckwheat sprouts supplement with exogenous growth regulators (BAP, kinetin, zeatin, and TDZ) which was shown in Table 1 . The treatment of TDZ resulted in the highest accumulations of the total phenolic compounds at the lowest concentrations $(0.1 \mathrm{mg} / \mathrm{L}$ of TDZ), whereas 0.5 and $1.0 \mathrm{mg} / \mathrm{L}$ of TDZ showed a slight decrease in the accumulations (Table 1). The total phenolic compounds were observed after supplement of $0.1 \mathrm{mg} / \mathrm{L} \mathrm{TDZ}$ $(29.86 \pm 0.26 \mathrm{mg} / \mathrm{g} \mathrm{DW})$, which is 1.24-, 1.27-, 1.19-, and 1.4l- times higher than the control, $0.1 \mathrm{mg} / \mathrm{L}$ of BAP, kinetin, zeatin treatment. Particularly, the levels of 4-hydroxybenzoic acid, caffeic acid, and rutin content were significantly increased in all the growth regulator treatments. The highest levels of rutin obtained after treatment of $0.1 \mathrm{mg} / \mathrm{LTDZ}$, which is 1.26- times higher than the control. However, the TDZ treatment led to a gradually decreased accumulation of chlorogenic acid, trans-cinnamic acid, and p-coumaric acid depending on all the concentrations. The second-highest total phenolic content after growth regulator treatment was obtained $1.0 \mathrm{mg} / \mathrm{L}$ of kinetin $(29.59 \pm 1.04 \mathrm{mg} / \mathrm{g} \mathrm{DW})$. In the kinetin treatment, the individual phenolic compound $(\mathrm{mg} / \mathrm{g} \mathrm{DW})$ is highest in the following orders rutin $(28.73 \pm 1.07)$, caffeic acid $(0.58$ $\pm 0.02)$, 4-hydroxybenzoic acid $(0.16 \pm 0.01)$. The thirdhighest total phenolic content was achieved in BAP hormonal treatment, among the individual phenolic compound levels the 4-hydroxybenzoic acid, caffeic acid, and rutin content. From these result, it is showed that different growth regulator has a significant effect on the different phenolic compound accumulation in the hormonal treatment, especially in higher TDZ treatment.

The result of different growth regulators on the accumulation of phenolic compounds showed that the highest total phenolic content was obtained in the $0.1 \mathrm{mg} / \mathrm{L}$ TDZ (29.86 \pm 0.26$)$, followed by $1 \mathrm{mg} / \mathrm{L}$ kinetin $(29.59 \pm 1.04), 1 \mathrm{mg} / \mathrm{L}$ BAP (27.36 \pm 0.56$)$, and $1 \mathrm{mg} / \mathrm{L}$ zeatin $(24.95 \pm 2.39)$. A similar result was obtained in the callus culture of Artemisia absinthium which showed that TDZ positively enhances the production of phenolic content. In addition, they found that at lowest TDZ concentration $(0.5-3.0 \mathrm{mg} / \mathrm{L})$ exhibited the highest total phenolic compounds and antioxidant activity (Ali \& Abbasi, 2014).

\section{CONCLUSIONS}

This study shows the effect of various growth regulators (BAP, kinetin, zeatin, and TDZ) on the growth development of Tartary buckwheat sprouts. Among these, BAP showed strong improvement in the growth parameters when compared to the control and other growth regulators. Hence, BAP is one of the good cytokinins which has the best morphogenic ability when compared to other plant growth regulators in the Tartary buckwheat sprout. HPLC analysis shows that when compared to BAP, kinetin, and zeatin, the TDZ is highly effective in 
the accumulation of the phenolic compounds during Tartary buckwheat sprout development.

\section{ACKNOWLEDGEMENTS}

This research was supported by the Basic Science Research Program through the National Research Foundation of Korea (NRF) funded by the Ministry of Education (NRF2019R1F1Al061916) and National Research Foundation of Korea (NRF-2019K2A9A2A06024347).

\section{REFERENCES}

Ahanhanzo, C., Gandonou, C., Agbidinoukoun, A., Dansi, A., \& Agbangla, C. (2010). Effect of two cytokinins in combination with acetic acid $\alpha$-naphthalene on yams (Dioscorea spp.) genotypes' response to in vitro morphogenesis. African Journal of Biotechnology, 9(51), 8837-8843.

Ali, M., \& Abbasi, B. H. (2014). Thidiazuron-induced changes in biomass parameters, total phenolic content, and antioxidant activity in callus cultures of Artemisia absinthium L. Applied Biochemistry and Biotechnology, 172(5), 2363-2376. https://doi.org/10.1007/s12010013-0663-7

Amarowicz, R., Dykes, G. A., \& Pegg, R. B. (2008). Antibacterial activity of tannin constituents from Phaseolus vulgaris, Fagoypyrum esculentum, Corylus avellana and Juglans nigra. Fitoterapia, 79(3), 217-219. https://doi.org/10.1016/j.fitote.2007.11.019

Cho, G., Kim, D., Pedersen, H., \& Chin, C.K. (1988). Ethephon enhancement of secondary metabolite synthesis in plant cell cultures. Biotechnology progress, 4(3), 184-188. https://doi.org/10.1002/btpr.5420040309

Danihelová, M., Jantová, S., \& Šturdík, E. (2013). Cytotoxic and antioxidant activity of buckwheat hull extracts. Journal of Microbiology, Biotechnology and Food Sciences, 2(1), 1748-1757.

Davies, P. J. (2010). The plant hormones: their nature, occurrence, and functions. Plant hormones. Springer

De Langhe, E., \& Vuylstek, D. (1985). Feasibility of in vitro propagation of banana and plantains. Tropical Agriculture, 62, 323-328.

Dixon, R. A., \& Paiva, N. L. (1995). Stress-induced phenylpropanoid metabolism. The Plant Cell, 7(7), 1085. https://doi.org/10.1105/ tpc.7.7.1085

El Kbiach, M., Lamarti, A., Abdali, A., \& Badoc, A. (2002). Culture in vitro des bourgeons axillaires de chêne-liège (Quercus suber L.) I-Influence des cytokinines sur l'organogenèse et la callogenèse de noeuds de plantules. Bulletin de la Société de Pharmacie de Bordeaux, 141, 73-88.

Gaspar, T., Kevers, C., Penel, C., Greppin, H., Reid, D.M., \& Thorpe, T. A. (1996). Plant hormones and plant growth regulators in plant tissue culture. In vitro Cellular and Developmental Biology-Plant, 32, 272289. https://doi.org/10.1007/BF02822700

Golisz, A., Lata, B., Gawronski, S. W., \& Fujii, Y., (2007). Specific and total activities of the allelochemicals identified in buckwheat. Weed Biology and Management, 7(3), 164-171. https://doi.org/10.1111/ j.1445-6664.2007.00252.x

Gulpinar, A. R., Orhan, I. E., Kan, A., Senol, F. S., Celik, S. A., \& Kartal, M. (2012). Estimation of in vitro neuroprotective properties and quantification of rutin and fatty acids in buckwheat (Fagopyrum esculentum Moench) cultivated in Turkey. Food Research International, 46(2), 536-543. https://doi.org/10.1016/j.foodres.2011.08.011

Han, S. -Y., Chu, J. -X., Li, G. -M., Zhu, L. -S., \& Shi, R. -F. (2010). Effects of rutin from leaves and flowers of buckwheat (Fagopyrum esculentum Moench.) on angiotensin II-induced hypertrophy of cardiac myocytes and proliferation of fibroblasts. Latin American Journal of Pharmacy, 29(1), 137-140.

Hou, S., Sun, Z., Linghu, B., Wang, Y., Huang, K., Xu, D., \& Han, Y. (2015). Regeneration of buckwheat plantlets from hypocotyl and the influence of exogenous hormones on rutin content and rutin biosynthetic gene expression in vitro. Plant Cell, Tissue and Organ Culture, 120, 1159-1167. https://doi.org/10.1007/s11240-014-0671-5

Hunter, S., Hannon, M., Foxe, M., \& Hennerty, M. (1984). Factors affecting the in vitro production of strawberry (Fragaria X anannassa Duch.) meristems (cv. Cambridge Favorite). Journal of Life Sciences Royal Dublin Society, 5, 13-19.

Jeon, Y. -J., Kang, E. -S., \& Hong, K. -W. (2007). A PCR method for rapid detection of buckwheat ingredients in food. Applied Biological Chemistry, 50(4), 276-280.

Jiang, P., Burczynski, F., Campbell, C., Pierce, G., Austria, J., \& Briggs, C. (2007). Rutin and flavonoid contents in three buckwheat species Fagopyrum esculentum, F. tataricum, and F. homotropicum and their protective effects against lipid peroxidation. Food Research International, 40(3), 356-364. https://doi.org/10.1016/j. foodres.2006.10.009

Kalinova, J., Triska, J., \& Vrchotova, N. (2006). Distribution of vitamin E, squalene, epicatechin, and rutin in common buckwheat plants (Fagopyrum esculentum Moench). Journal of Agricultural and Food Chemistry, 54(15), 5330-5335. https://doi.org/10.1021/jf060521r

Karuppusamy, S. (2009). A review on trends in production of secondary metabolites from higher plants by in vitro tissue, organ and cell cultures. Journal of Medicinal Plants Research, 3(13), 1222-1239. https://doi.org/10.5897/JMPR.9000026

Kim, C. D., Lee, W. -K., No, K. -O., Park, S. -K., Lee, M.-H., Lim, S. R., \& Roh, S. -S. (2003). Anti-allergic action of buckwheat (Fagopyrum esculentum Moench) grain extract. International Immunopharmacology, 3(1), 129-136. https://doi.org/10.1016/s1567-5769(02)00261-8

Kim, D. W., Hwang, I. K., Lim, S. S., Yoo, K. Y., Li, H., Kim, Y. S., Kwon, D. Y., Moon, W. K., Kim, D. W., \&Won, M. H. (2009). Germinated buckwheat extract decreases blood pressure and nitrotyrosine immunoreactivity in aortic endothelial cells in spontaneously hypertensive rats. Phytotherapy Research: An International Journal Devoted to Pharmacological and Toxicological Evaluation of Natural Product Derivatives, 23(7), 993-998. https://doi.org/10.1002/ptr.2739

Kim, S. -H., Cui, C. -B., Kang, I. -J., Kim, S. Y., \& Ham, S. -S. (2007). Cytotoxic effect of buckwheat (Fagopyrum esculentum Moench) hull against cancer cells. Journal of Medicinal Food, 10(2), 232-238. https://doi. org/10.1089/jmf.2006.1089

Kim, S. -J., Zaidul, I., Suzuki, T., Mukasa, Y., Hashimoto, N., Takigawa, S., Noda, T., Matsuura-Endo, C., \& Yamauchi, H. (2008). Comparison of phenolic compositions between common and tartary buckwheat (Fagopyrum) sprouts. Food Chemistry, 110(4), 814-820. https://doi. org/10.1016/j.foodchem.2008.02.050

Kreft, I., Fabjan, N., \& Yasumoto, K. (2006). Rutin content in buckwheat (Fagopyrum esculentum Moench) food materials and products. Food Chemistry, 98(3), 508-512. https://doi.org/10.1016/j. foodchem.2005.05.081

Kumar, S., \& Pandey, A. K. (2013). Chemistry and biological activities of flavonoids: an overview. The Scientific World Journal, 162750. https:// doi.org/10.1155/2013/162750

Lee, C. -C., Shen, S. -R., Lai, Y. -J., \& Wu, S. -C. (2013). Rutin and quercetin, bioactive compounds from tartary buckwheat, prevent liver inflammatory injury. Food and Function, 4(5), 794-802. https://doi. org/10.1039/c3fo30389f

Mantell, S. H., \& Hugo, S. A. (1989). Effects of photoperiod, mineral medium strength, inorganic ammonium, sucrose and cytokinin on root, shoot and microtuber development in shoot cultures of Dioscorea alata L. and D. bulbifera L. yams. Plant Cell, Tissue and Organ Culture, 16 23-37. https://doi.org/10.1007/BF00044069

Montcho, D. (2004). Impact des facteurs chimiques sur la multiplication in vitro de quelques génotypes d'igname du Bénin. Mémoire de DEA biotechnologies, FAST/UAC, Bénin, pp. 42.

Park, C. H., AyeThwe, A., Kim, S. J., Park, J. S., Arasu, M., Al-Dhabi, N. A., Park, N. I., \& Park, S. U. (2016). Effect of auxins on anthocyanin accumulation in hairy root cultures of Tartary buckwheat cultivar Hokkai T10. Natural Product Communications, 11(9), 1283-1286. https://doi.org/10.1177/1934578X1601100924

Rao, S. R., \& Ravishankar, G. (2002). Plant cell cultures: chemical factories of secondary metabolites. Biotechnology Advances, 20(2), 101-153. https://doi.org/10.1016/s0734-9750(02)00007-1

Ren, S. -C., \& Sun, J. -T. (2014). Changes in phenolic content, phenylalanine ammonia-lyase (PAL) activity, and antioxidant capacity of two buckwheat sprouts in relation to germination. Journal of Functional Foods, 7, 298-304. https://doi.org/10.1016/j.jff.2014.01.031

Saleil, V., Degras, L., \& Jonard, R. (1990). Obtention de plantes indemnes du virus de la mosaïque de l'igname (YMV) par culture in vitro des apex chez l'igname americaine Dioscorea trifida L. Agronomie, $10,605-615$ 
Sandhu, A. K., Gray, D. J., Lu, J., \& Gu, L. (2011). Effects of exogenous abscisic acid on antioxidant capacities, anthocyanins, and flavonol contents of muscadine grape (Vitis rotundifolia) skins. Food Chemistry, 126(3), 982-988. https://doi.org/10.1016/j.foodchem.2010.11.105

Thiruvengadam, M., Kim, S. -H., \& Chung, I. -M. (2015). Exogenous phytohormones increase the accumulation of health-promoting metabolites, and influence the expression patterns of biosynthesis related genes and biological activity in Chinese cabbage (Brassica rapa spp. pekinensis). Scientia Horticulturae, 193, 136-146. https:// doi.org/10.1016/j.scienta.2015.07.007

Toklo, M. (2000). Contribution à la micropropagation, la vitromycorhisation et la bactérisation du bananier (Musa sp) et de l'igname (Dioscorea sp). Thčse de. 3, 104.

Vanisree, M., Lee, C. -Y., Lo, S. -F., Nalawade, S. M., Lin, C. Y., \& Tsay, H. -S. (2004). Studies on the production of some important secondary metabolites from medicinal plants by plant tissue cultures. Botanical Bulletin of Academia Sinica, 45, 1-22.

Winkel, S. B. (2001). Flavonoid biosynthesis. A colorful model for genetics, biochemistry, cellbiology, and biotechnology. Plant Physiology, 126(2), 485-493. https://doi.org/10.1104/pp.126.2.485

Watanabe, M., \& Ayugase, J. (2010). Effects of buckwheat sprouts on plasma and hepatic parameters in type 2 diabetic $\mathrm{db} / \mathrm{db}$ mice. Journal of Food Science, 75(9), H294-H299. https://doi.org/10.1111/j.17503841.2010.01853.x

Yahia, A., Kevers, C., Gaspar, T., Chénieux, J. -C., Rideau, M., \& Crèche, J. (1998). Cytokinins and ethylene stimulate indole alkaloid accumulation in cell suspension cultures of Catharanthus roseus by two distinct mechanisms. Plant Science, 133(1), 9-15. https://doi.org/10.1016/ S0168-9452(98)00014-4

Yeo, H. J., Baek, S. -A., Sathasivam, R., Kim, J. K., \& Park, S. U. (2021). Metabolomic analysis reveals the interaction of primary and secondary metabolism in white, pale green, and green pak choi (Brassica rapa subsp. chinensis). Applied Biological Chemistry, 64(3), 1-16. https://doi.org/10.1186/s13765-020-00574-2

Yeoman, M., \& Yeoman, C. (1996). Manipulating secondary metabolism in cultured plant cells. New Phytologist, 553-569. https://doi. org/10.1111/j.1469-8137.1996.tb04921.x

Zhang, J., Gao, W. -Y., Wang, J., \& Li, X. -L. (2012). Effects of sucrose concentration and exogenous hormones on growth and periplocin accumulation in adventitious roots of Periploca sepium Bunge. Acta Physiologiae Plantarum, 34, 1345-1351. https://doi.org/10.1007/ s11738-012-0931-0 